\title{
Microalgae Cultivation in Wastewater From Agricultural Industries to Benefit Next Generation of Bioremediation: A Bibliometric Analysis
}

Jessica Muniz Melo

Instituto de Desenvolvimento Rural do Paraná lapar-Emater Londrina: Instituto de Desenvolvimento Rural do Parana lapar-Emater Londrina

Marina Ronchesel Ribeiro Instituto de Desenvolvimento Rural do Paraná lapar-Emater Londrina: Instituto de Desenvolvimento Rural do Parana lapar-Emater Londrina

\section{Tiago Santos Telles}

Instituto de Desenvolvimento Rural do Paraná lapar-Emater Londrina: Instituto de Desenvolvimento Rural do Parana lapar-Emater Londrina

Higo Forlan Amaral

UniFil: Centro Universitario Filadelfia

Diva Souza Andrade ( $D$ 2013divaandrade@gmail.com )

Institute Agronomic of Parana State https://orcid.org/0000-0003-0761-004X

\section{Research Article}

Keywords: algae, effluent, environmental impact, coffee industry, cassava industry, dairy industry

Posted Date: June 1st, 2021

DOI: https://doi.org/10.21203/rs.3.rs-427996/v1

License: (c) (1) This work is licensed under a Creative Commons Attribution 4.0 International License. Read Full License

Version of Record: A version of this preprint was published at Environmental Science and Pollution Research on November 19th, 2021. See the published version at https://doi.org/10.1007/s11356-02117427-0. 


\section{Abstract}

The aim of this study is to provide a bibliometric analysis and mapping of existing scientific papers, focusing on microalgae cultivation coupled with biomass production and bioremediation of wastewater from cassava, dairy, and coffee industries. Using the Web of Science (WoS) database for the period 1996-2019, a search was performed using a keyword strategy, aiming at segregating the papers in groups. The keywords used in this search were "wastewater treatment," "microalgae," "cassava," "dairy," and "coffee" for the first step, resulting in 114 papers; for the second step, we used the keywords "wastewater treatment," "biomass productivity," "microalgae," "economic viability," and "environmental impacts," which resulted in 29 scientific papers. In these papers, keywords such as "carbon dioxide biofixation" and "removal of nutrients by the production of biomass by microalgae" followed by "environmental and economic impacts" were highlighted. Some of these papers also presented an analysis of the economic feasibility of the process, including costs of production systems, which reveal the state-of-the-art setup required to make the cultivation of microalgae economically viable. Research in eco-industrial parks is needed to improve the integration of microalgae production systems using wastewater as a source of nutrients, aiming to achieve the global goal of bioremediation and clean alternatives for renewable energy generation.

\section{Introduction}

Microalgae are photosynthetic microorganisms capable of growing in industrial effluents, producing a biomass rich in oils and carbohydrates, which are the raw materials for generating clean energy and biofertilizers; they contribute to the bioremediation process simultaneously (Andrade et al., 2021; Woertz et al., 2009). Wastewater can be used to grow microalgae in the chain production process as a sustainable water source and as a medium rich in nutrients, containing organic carbon source for the heterotrophic and mixotrophic groups (Andrade et al., 2020; Lowrey et al., 2015). For instance, the Scenedesmus obliquus cultivated in municipal wastewater achieved higher lipid and carbohydrate than those grown in synthetic medium (Ansari et al., 2019). For palm oil mill wastewater treatment, Emparan et al. (2020) indicated Nannochloropsis sp. as an option to produce microalgae biomass simultaneously.

Our study analyzed articles that focused on the cultivation of microalgae in wastewater from three types of agro-industrial companies that processed soluble coffee, cassava, and dairy products. Coffee is one of the most consumed beverages in the world (Mussatto et al., 2011); the industrial processing of coffee beans generates enormous amounts of wastewater having high contents of organic matter, known to induce serious environmental risks (Panchangam and Janakiraman, 2015). Wastewater from cassava (Manihot esculenta Crantz) contains a higher concentration of organic and inorganic chemicals, such as carbohydrates, ammonia, calcium, chloride, inorganic phosphate, magnesium, nitrate, organic carbon, organic phosphorus, potassium, sodium, and sulfate (Selvan et al., 2019). Wastewater from the dairy industry has been described as an excellent source of nutrients for microalgae growth (Gonçalves et al., 2017). The cultivation of microalgae in dairy effluents (which is rich in C:N:P) replaces the culture medium containing mineral nutrients and fresh water generally used for microalgae cultivation, thereby 
reducing the cost of production (Kumar et al., 2020). According to Valizadeh and Davarpanah (2020), biological purification of dairy effluents is an efficient and essential approach that leads to a healthy and clean environmental ecosystem.

According to the search terms, textual mining scanning is important in identifying scientific publications and still allows the mapping of scientific development, in addition to showing the growing interest in the topic addressed. In our study, bibliometric mapping was applied to verify the main topics discussed in the existing literature and investigate the associations among the most cited words, such as the association of "bioremediation of agro-industrial effluents" with "microalgae cultivation," along with understanding the economic and environmental viability of these projects.

Bibliometric studies have re-explored the research in microalgae on a global scale (Garrido-Cardenas et al., 2018), with a focus on microalgae bioproducts (de Souza et al., 2019), highlighting the microalgae biomass market and their products (Rumin et al., 2020), microalgae-derived biodiesel (Ma et al., 2018), microalgae wastewater bioremediation (Pacheco et al., 2020) and algal species, products, and pretreatment techniques used for extraction (de Carvalho et al., 2020).

In this framework, our study aims to perform a temporal bibliometric analysis of articles focused on the cultivation of microalgae coupled with the bioremediation of wastewater from cassava, dairy, and coffee industries to identify specific and relevant publications in the literature using specific terms and examining their connections with different countries and the most cited articles.

\section{Methodology}

For bibliometric analysis, it was applied the procedures described by Cobo et al. (2011) as follows: (i) detect the topics treated by research fields, (ii) search by keywords in the literature/data collection, (iii) quality/preprocessing evaluation, (iv) visualize themes and thematic links, (v) visualize the different map elements (clusters) and network, (vi) synthesis and data analysis, and (vii) interpretation of the results. Bibliometric analysis was performed in the main collection of WoS of the Thomson Reuters Institute of Scientific Information (ISI) from January 1, 1996, to December 31, 2019, using two steps. The following keywords: "wastewater treatment," AND "microalgae," AND "cassava," OR "dairy," OR "coffee" were used for the first step. For the second step, we considered the following keywords: "wastewater treatment," "biomass productivity," AND "microalgae," AND "economic viability," OR "environmental impacts." Based on the keywords, 184 papers were found in the first step and 33 were found in the second. After applying the exclusion criteria for duplication and review papers, 114 and 29 papers were selected from the first and second steps, respectively, and used for cluster analyses.

We used the VOSviewer 1.6.13 software for "Cluster" based on the text data from the previously exported WoS database. The flowchart generated through the terms was extracted using the keywords "complete record" and "cited references," and the binary count used was based on the minimum occurrence of a term. We used the first and second steps for the geographical distribution of publications and summarized the highly cited papers (Table 1 ). 
Table 1

Summary of the main articles related to the terms of the Research 1 ("wastewater treatment", "microalgae" and "cassava OR dairy OR coffee") and Research 2 ("wastewater treatment", "biomass productivity", "microalgae" and "economic viability OR environmental impacts"), in the WoS database, from 1996 to 2019

\begin{tabular}{|c|c|c|c|}
\hline Article title & $\begin{array}{l}\text { No } \\
\text { citation }\end{array}$ & Country filiation & Reference \\
\hline $\begin{array}{l}\text { Dual role of microalgae: Phycoremediation } \\
\text { of domestic wastewater and biomass } \\
\text { production for sustainable biofuels } \\
\text { production }\end{array}$ & 435 & South Africa & $\begin{array}{l}\text { (Rawat et } \\
\text { al., 2011) }\end{array}$ \\
\hline $\begin{array}{l}\text { Algae grown on dairy and municipal } \\
\text { wastewater for simultaneous nutrient } \\
\text { removal and lipid production for biofuel } \\
\text { feedstock }\end{array}$ & 260 & USA & $\begin{array}{l}\text { (Woertz et } \\
\text { al., 2009) }\end{array}$ \\
\hline $\begin{array}{l}\text { Development of an attached microalgal } \\
\text { growth system for biofuel production }\end{array}$ & 194 & USA & $\begin{array}{l}\text { (Johnson } \\
\text { and Wen, } \\
\text { 2010) }\end{array}$ \\
\hline $\begin{array}{l}\text { Efficiency of ammonia and phosphorus } \\
\text { removal from a Colombian agroindustrial } \\
\text { wastewater by the microalgae Chlorella } \\
\text { vulgaris and Scenedesmus dimorphus }\end{array}$ & 191 & Mexico & $\begin{array}{l}\text { (González et } \\
\text { al., 1997) }\end{array}$ \\
\hline $\begin{array}{l}\text { Rotating algal biofilm reactor and spool } \\
\text { harvester for wastewater treatment with } \\
\text { biofuels by-products }\end{array}$ & 154 & USA & $\begin{array}{l}\text { (Christenson } \\
\text { and Sims, } \\
\text { 2012) }\end{array}$ \\
\hline $\begin{array}{l}\text { Reuse of effluent water from a municipal } \\
\text { wastewater treatment plant in microalgae } \\
\text { cultivation for biofuel production }\end{array}$ & 141 & South Korea & $\begin{array}{l}\text { (Cho et al., } \\
2011 \text { ) }\end{array}$ \\
\hline $\begin{array}{l}\text { Food waste as nutrient source in } \\
\text { heterotrophic microalgae cultivation }\end{array}$ & 116 & Peoples R. China & $\begin{array}{l}\text { (Pleissner et } \\
\text { al., 2013) }\end{array}$ \\
\hline $\begin{array}{l}\text { Neochloris oleoabundans grown on } \\
\text { anaerobically digested dairy manure for } \\
\text { concomitant nutrient removal and biodiesel } \\
\text { feedstock production }\end{array}$ & 97 & USA & $\begin{array}{l}\text { (Levine et } \\
\text { al., 2011) }\end{array}$ \\
\hline $\begin{array}{l}\text { Anaerobic digestate as substrate for } \\
\text { microalgae culture: The role of ammonium } \\
\text { concentration on the microalgae productivity }\end{array}$ & 89 & France & $\begin{array}{l}\text { (Uggetti et } \\
\text { al., 2014) }\end{array}$ \\
\hline $\begin{array}{l}\text { The effect of bacterial contamination on the } \\
\text { heterotrophic cultivation of Chlorella } \\
\text { pyrenoidosa in wastewater from the } \\
\text { production of soybean products }\end{array}$ & 81 & Peoples R. China & $\begin{array}{l}\text { (Zhang et } \\
\text { al., 2012) }\end{array}$ \\
\hline $\begin{array}{l}\text { Experimental study for growth potential of } \\
\text { unicellular alga Chlorella pyrenoidosa on } \\
\text { dairy waste water: An integrated approach } \\
\text { for treatment and biofuel production }\end{array}$ & 73 & India & $\begin{array}{l}\text { (Kothari et } \\
\text { al., 2012) }\end{array}$ \\
\hline
\end{tabular}




\begin{tabular}{|c|c|c|c|}
\hline Article title & $\begin{array}{l}\text { No } \\
\text { citation }\end{array}$ & Country filiation & Reference \\
\hline $\begin{array}{l}\text { Scale-up potential of cultivating Chlorella } \\
\text { zofingiensis in piggery wastewater for } \\
\text { biodiesel production }\end{array}$ & 70 & Peoples R. China/Finland & $\begin{array}{l}\text { (Zhu et al., } \\
\text { 2013) }\end{array}$ \\
\hline $\begin{array}{l}\text { Effects of cassava starch hydrolysate on cell } \\
\text { growth and lipid accumulation of the } \\
\text { heterotrophic microalgae Chlorella } \\
\text { protothecoides }\end{array}$ & 60 & Peoples R. China/USA & $\begin{array}{l}\text { (Wei et al., } \\
\text { 2009) }\end{array}$ \\
\hline $\begin{array}{l}\text { From waste to energy: Microalgae production } \\
\text { in wastewater and glycerol }\end{array}$ & 60 & Spain/Brazil & $\begin{array}{l}\text { (Cabanelas } \\
\text { et al., 2013) }\end{array}$ \\
\hline $\begin{array}{l}\text { Biodiesel production from algal oil using } \\
\text { cassava (Manihot esculenta Crantz) as } \\
\text { feedstock }\end{array}$ & 52 & Peoples R. China & $\begin{array}{l}\text { (Lu et al., } \\
2010 \text { ) }\end{array}$ \\
\hline $\begin{array}{l}\text { Microalgal biomass and lipid production in } \\
\text { mixed municipal, dairy, pulp and paper } \\
\text { wastewater together with added flue gases }\end{array}$ & 48 & Sweden & $\begin{array}{l}\text { (Gentili, } \\
\text { 2014) }\end{array}$ \\
\hline $\begin{array}{l}\text { Cyanobacterial process for renovating dairy } \\
\text { wastewater }\end{array}$ & 48 & USA & $\begin{array}{l}\text { (Lincoln et } \\
\text { al., 1996) }\end{array}$ \\
\hline $\begin{array}{l}\text { Impact of ammonia concentration on } \\
\text { Spirulina platensis growth in an airlift } \\
\text { photobioreactor }\end{array}$ & 48 & USA/Netherlands/Norway & $\begin{array}{l}\text { (Yuan et al., } \\
\text { 2011) }\end{array}$ \\
\hline $\begin{array}{l}\text { Enhancement of energy production efficiency } \\
\text { from mixed biomass of Chlorella } \\
\text { pyrenoidosa and cassava starch through } \\
\text { combined hydrogen fermentation and } \\
\text { methanogenesis }\end{array}$ & 46 & Peoples R. China & $\begin{array}{l}\text { (Xia et al., } \\
2014)\end{array}$ \\
\hline $\begin{array}{l}\text { High rate algal pond systems for low-energy } \\
\text { wastewater treatment, nutrient recovery and } \\
\text { energy production }\end{array}$ & 44 & New Zealand & $\begin{array}{l}\text { (Craggs et } \\
\text { al., 2014) }\end{array}$ \\
\hline
\end{tabular}

\section{Results And Discussion}

\section{Microalgae biomass using wastewater}

The clusters obtained in the first step showed significant clustering matching to microalgae bioremediation of dairy, cassava, and coffee wastewater themes. The main link among the clusters is due to the term "microalgae". The keywords of the articles were as follows: (i) dairy wastewater related to the removal of nutrients and associated with $C$. vulgaris and $C$. pyrenoidosa (red cluster); (ii) cassava starch to obtain lipids related to $C$. protothecoides (yellow cluster); and (iii) use of coffee wastewater associated with anaerobic digestion and cyanobacteria (blue, green, and purple clusters) (Fig. 1).

Understanding the connections among the groups is important because they refer to the use of microalgae for the bioremediation of agro-industrial effluents. 
Studies that used microalgae for dairy wastewater treatment aimed to develop a technology to produce raw materials for low-cost biodiesel production. For instance, Woertz et al. (2009) investigated the lipid productivity and the removal of nutrients by green microalgae cultivated in dairy wastewater, which was supplemented by $\mathrm{CO}_{2}$ due to carbon limitation that accelerated microalgae growth. In addition, Johnson and Wen (2010) cultivated Chlorella sp. in dairy wastewater using foam to perform cell fixation, which resulted in better biomass and fatty acid yield. Additionally, Kothari et al. (2012) used C. pyrenoidosa in two stages: in the first stage, the wastewater quality parameters were evaluated, and nutrient removal was assessed for nitrogen and phosphorus; in the second stage, high oil and fat production was verified. Labbé et al. (2017) reported that Chlorella sp. and Scenedesmus sp. were capable of growing in different dairy farm effluents, showing that there is potential in using microalgae growth for treating these effluents and improving the finances of small and medium dairy farms.

There are few publications on the cultivation of microalgae in cassava wastewater ("manipueira"), aiming at the treatment of this effluent through algal biomass production. Yang, Ding, and Zhang (2008) used cassava powder as a raw material for $C$. pyrenoidosa cultivation in undiluted wastewater from ethanol fermentation to generate biomass, regulate the $\mathrm{pH}$, and reduce the chemical oxygen demand (COD). However, the focus of some related studies on cassava is on organic carbon supplementation in the microalgae culture medium to increase biomass production. The use of this organic carbon source is justified by the reduction in costs, in addition to increasing biomass production and lipid accumulation (Wei et al., 2009).

Publications address the use of microalgae in the industrial process of manufacturing cassava, aiming at the improvement, simplification, and optimization of production steps; for example, a study implements the simultaneous saccharification of cassava starch (using enzymes) and fermentation (using $C$. protothecoides) to avoid hydrolysis in several stages of the process (Lu et al., 2010). Another study reported that when $C$. vulgaris was grown mixotrophically in hydrolyzed cassava waste powder, the protein content and protein productivity of the biomass increased (Abreu et al., 2012). A study using Scenedesmus sp., which was cultured to enhance the lipid production and nutrient removal from tapioca wastewater (Romaidi et al., (2018) showed the potential of using this microorganism to produce raw material for bioenergy and wastewater bioremediation.

Using different exogenous sources of organic carbon in heterotrophic growth, such as cassava starch, the $\mathrm{C} / \mathrm{N}$ ratio appears to be a significant factor affecting the metabolism performance of cyanobacterium Aphanothece microscopica Nägeli (Meireles dos Santos et al., 2017); therefore, this parameter should be carefully examined to gather valuable information on how to optimize and control the performance of cultivation systems.

The feasibility of increasing bioenergy production by fermentation of non-detoxified cassava bagasse hydrolysate as an alternative carbon source for microalgae biomass production was highlighted by Lu et al. (2010) using $C$. protothecoides and by Liu (2018) with a consortium of $C$. pyrenoidosa and red yeast Rhodotorula glutinis. Using different residues, Sun et al. (2019) showed that the addition of $C$. 
pyrenoidosa biomass to rice residue and in thermo-chemical hydrolysis and biological acidification processes enhanced gaseous biofuel production during the anaerobic digestion of the raw material mixture in a short time.

Among the publications that address microalgae growing in coffee wastewater, a study by Posadas et al. (2014) was identified that evaluated a consortium of microalgae (Phormidium, Oocystis, and Microspora) and bacteria from activated sludge in five distinct fresh effluents from different agro-industries, one of them being from a lyophilized-coffee manufacturing factory. The authors detected low biodegradability, but found interesting results for nutrient recovery and microbial biomass generation.

\section{Economic and environmental analyses associated with microalgae cultivation}

The clusters obtained in the second search show the different approaches identified by the keywords related to terms such as "economic viability" and "environmental impacts." Four groups were identified: (i) blue cluster: wastewater as a nutrient source for biodiesel generation; (ii) yellow cluster: microalgae for energy production, and clean and renewable energy sources; (iii) green cluster: microalgae cultivation to increase biomass and oil productivity, carbon dioxide biofixation, cost terms, large-scale production, techno-economic analysis, and nutrient removal; and (iv) red cluster: biodiesel production from biomass generated through microalgae cultivation (Fig. 2).

The integration of microalgae cultivation using the treatment of agro-industrial wastewater in the production of biofuels is a promising solution. The main link among the clusters is due to the term's "growth" and "biodiesel production". In addition to microalgae cultivation, the growth term is associated with the selection of strains that best adapt to the medium and thus, obtain higher biomass productivity; therefore, the other prominent term is "biodiesel production," which is directly linked to the microalgae biomass acquisition process. This is because, with the decrease in fossil fuel reserves and environmental deterioration, studies involving microalgae and renewable energy sources are gaining prominence because they offer more economic and sustainable technologies.

Algae biodiesel has been the target of numerous studies because of the reduction of greenhouse gases compared to fossil fuels (Benemann et al., 2012). In addition, microalgae can be used to generate other derived chemicals, such as bioethanol, biokerosene, bioplastics, hydrogen biofuels, and biogas (Chisti and Yan, 2011).

Biofuels derived from microalgae are still not commercially viable because their costs are higher than gasoline (Cruce and Quinn, 2019). Thus, the sustainability of projects that aim to cultivate microalgae for the production of biofuels and other bioproducts is generally evaluated using technoeconomic analysis and/or life cycle assessment (LCA) (Grierson et al., 2013). One of the main "bottlenecks" highlighted by several authors with respect to the implementation of microalgae cultivation systems are the high costs arising from these processes. These can be defined as the sum of used energy, installation, pond downtime, capital costs (investment), operational, maintenance, and environmental issues, among others 
(Dasan et al., 2019; Strazza et al., 2015), and determinants for the implementation of algal biomass production systems (because they can result in negative economic performance).

Aiming increase the production of biofuels from microalgae, future studies should focus on the areas of biotechnology and synthetic biology related to the efficient production of several bioproducts of economic interest, overcoming the previously mentioned bottleneck (Chen et al., 2019). Besides the economic aspects, microalgae projects are garnering interest due to the reduction in their environmental impacts. Agro-industrial residues are abundant and easily available. When not treated, wastewater contains nitrogen and phosphorus, which can lead to eutrophication and environmental problems, affecting bio-system recycling (Umamaheswari and Shanthakumar, 2016). The irregular disposal of wastewater compromises the environment because the soil, when receiving constant loads above the necessary, can change its characteristics and consequently the water bodies that its holds. The changes in water quality are mainly due to the polluting agents in the water; changing the water quality from the presence of nutrients leads to the eutrophication process (disordered growth of algae and macrophytes) that interferes with water use and ecosystem balance.

Microalgae are photosynthetic microorganisms and reduce greenhouse by $\mathrm{CO}_{2}$ fixation, even when they are growing mixotrophically using organic carbon from wastewater (De Bhowmick et al., 2014); for instance, the production of $1.0 \mathrm{~kg}$ of microalgae biomass can fix up to $1.83 \mathrm{~kg}$ of $\mathrm{CO}_{2}$ (Jiang et al., 2013).

The integration of microalgae cultivation with wastewater treatment significantly reduces the environmental impacts because it is an emerging technology, and the use of agricultural and industrial waste for microalgae cultivation ensures sustainability and reduces the high costs of cultivation. Agroindustry integration through microalgal cultivation is an economically feasible and ecologically sustainable approach for wastewater treatment, bioenergy production chain, and the food industry (Andrade et al., 2020; de Carvalho et al., 2020).

\section{Geographical distribution of publications}

The importance of research on the treatment of agro-industry effluents using microalgae is represented in Figure 3, which shows the distribution of communities of countries that published studies in this area and the advancement of these publications over time. Before 2014, the USA, China, and Brazil had a higher density of publications based on the two searches. Subsequently, in 2016, India and Finland were relevant in the studies. In 2017, countries such as Greece and Iran gained interest and, finally, between 2018 and 2019, England, Qatar, Brunei (Asia), and Australia showed a high density of publications.

Overall, the number of papers showed that China, USA, and Brazil accounted for $45 \%$ of the total publications $(16.5 \%, 16.5 \%$, and $12 \%$, respectively), which can be explained by the importance of the agroindustrial sector in these countries.

Researchers' cooperation among countries and institutions highlights the importance of research involving microalgae and renewable energy sources of the 143 records found; 110 papers were written 
and developed by researchers of the same nationality. Moreover, 33 articles were elaborated in cooperation with researchers from other nationalities.

Four publications were developed in cooperation among different countries, highlighting the cooperation among Spanish and Brazilian researchers belonging to the Cadis University (UCA), Spain, and Federal University of Bahia, Brazil. The USA, in turn, developed cooperation with researchers from the Netherlands and Norway (Europe), in addition to studies developed together with Chinese researchers. China presented cooperation with researchers from Finland, in addition to its cooperation with USA.

\section{Future research trends on microalgae cultivation}

Studies that associate microalgae life cycle evaluation and economic technical analysis are essential to identify the paths to follow and achieve sustainability in bioenergy generation and bioproducts. The particularities and diversity of agro-industrial effluents can provide economic, environmental, and social resources from the use of microalgae in bioremediation and biomass production. The challenge of making the production of microalgae biofuels more accessible is due to the integration of biorefineries with respect to exploring other bioproducts of higher value, thus compensating the process production costs. For algae biofuels, electricity coproduction and high protein value products are the most studied in the literature, especially the study of algae flour as a food source (Cruce and Quinn, 2019).

According to Roth, Hoeltz, and Benitez (2020), Brazil is considered a pioneer in the development of technologies to produce renewable biofuels, although the country has fewer investments compared to the USA and European countries.

Fossil energy use is the main contributor to greenhouse gas emissions (GGE), and carbon dioxide emissions are the most common gas released by human activities, representing three-quarters of the global emissions of GGE (Dasan et al., 2019). Therefore, there is a need to develop renewable energy sources to meet the energy demands of the world.

In addition, public policies that benefit the cultivation of microalgae in agro-industrial effluents, through taxes on production (subsidies), financing for the sector, and carbon credits, are important to stimulate research, development, and innovation and integrate universities and public and private research agencies, while adding more and more research efforts to explore the cultivation of microalgae and their bioproducts.

\section{Conclusion}

The use of agro-industry wastewater in the microalgae production chain for biomass generation is a promising alternative to reduce costs and decrease environmental impacts. Large-scale research on microalgae production in agro-industrial effluents is essential to enable bioproduct generation projects and achieve sustainable and low-cost production of microalgae biomass. 
Economic and environmental analyses should be integrated to allow a large-scale project performance evaluation because the technologies arising from microalgae cultivation systems are essential to improve the viability of projects for bioproduct generation, resulting in environmental, economic, and social gains.

Bibliometric analysis, based on the Web of Science (WoS) database, which addresses the cultivation of microalgae and the treatment of agro-industrial wastewater, shows scientific gains regarding the development of alternative technologies to produce microalgae biomass, especially in the treatment of dairy wastewater. There is a gap in the publications indexed with the topic of cultivating microalgae to treat wastewater from the industrialization of cassava and coffee.

Further research is needed to optimize the biomass/lipid accumulation in microalgae cultivation and better understand the mechanisms underlying the enhanced wastewater treatment.

\section{Abbreviations}

WoS: Web of Sciences; COD: Chemical oxygen demand; LCA: Life cycle assessment; GGE: Greenhouse gas emissions

\section{Declarations}

\section{Ethics approval and consent to participate:}

Not applicable.

\section{Consent for publication:}

Not applicable.

\section{Availability of data and materials:}

Not applicable.

\section{Funding:}

This study was partially supported by the National Council for the Improvement of Higher Education (CAPES, 001) and by the INCT-CNPq (Brazilian National Council for Scientific and Technological Development) (MPCPAgro 465133/2014-2).

\section{Competing interest:}

The authors declare that they have no competing interests.

\section{Authors' contributions:}


DSA and TST: Conceptualization, Methodology, JMM and MRR: writing - original draft. DSA, TST and HFA: Supervision writing, review \& editing. All authors read and approved the final manuscript.

\section{Acknowledgments:}

JMM acknowledges MSc. scholarship from the National Council for the Improvement of Higher Education (CAPES). DSA and TST are also research fellows of Brazilian National Council for Scientific and Technological Development (CNPq) grants (315060/2020-4) and (315529/2020-2), respectively.

\section{References}

1. Abreu AP, Fernandes B, Vicente AA, Teixeira J, Dragone G (2012) Mixotrophic cultivation of Chlorella vulgaris using industrial dairy waste as organic carbon source Bioresour Technol 118:61-66 doi:https://doi.org/10.1016/j.biortech.2012.05.055

2. Andrade DS, Amaral HF, Gavilanes FZ, Morioka LRI, Nassar JM et al. (2021) Microalgae: Cultivation, Biotechnological, Environmental, and Agricultural Applications. In: Maddela N, Cruzatty LG, Chakraborty S (eds) Advances in the Domain of Environmental Biotechnology. Environmental and Microbial Biotechnology. Springer, Singapore, pp 635-701. doi:https://doi.org/10.1007/978-981-158999-7_23

3. Andrade DS, Telles TS, Leite Castro GH (2020) The Brazilian microalgae production chain and alternatives for its consolidation J Clean Prod 250:119526 doi:https://doi.org/10.1016/j.jclepro.2019.119526

4. Ansari FA, Ravindran B, Gupta SK, Nasr M, Rawat I et al. (2019) Techno-economic estimation of wastewater phycoremediation and environmental benefits using Scenedesmus obliquus microalgae J Environ Manage 240:293-302 doi:https://doi.org/10.1016/j.jenvman.2019.03.123

5. Benemann J, Woertz I, Lundquist T (2012) Life cycle assessment for microalgae oil production Disruptive Sci Technol 1:68-78 doi:https://doi.org/10.1089/dst.2012.0013

6. Cabanelas ITD, Arbib Z, Chinalia FA, Souza CO, Perales JA et al. (2013) From waste to energy: Microalgae production in wastewater and glycerol Appl Energy 109:283-290 doi:https://doi.org/10.1016/j.apenergy.2013.04.023

7. Chen H, Li T, Wang Q (2019) Ten years of algal biofuel and bioproducts: gains and pains Planta 249:195-219 doi:https://doi.org/10.1007/s00425-018-3066-8

8. Chisti Y, Yan J (2011) Energy from algae: Current status and future trends: Algal biofuels - A status report Appl Energy 88:3277-3279 doi:https://doi.org/10.1016/j.apenergy.2011.04.038

9. Cho S, Luong TT, Lee D, Oh Y-K, Lee T (2011) Reuse of effluent water from a municipal wastewater treatment plant in microalgae cultivation for biofuel production Bioresour Technol 102:8639-8645 doi:https://doi.org/10.1016/j.biortech.2011.03.037

10. Christenson LB, Sims RC (2012) Rotating algal biofilm reactor and spool harvester for wastewater treatment with biofuels by-products Biotechnol Bioeng 109:1674-1684 
doi:https://doi.org/10.1002/bit.24451

11. Cobo MJ, López-Herrera AG, Herrera-Viedma E, Herrera F (2011) An approach for detecting, quantifying, and visualizing the evolution of a research field: A practical application to the Fuzzy Sets Theory field J Informetr 5:146-166 doi:https://doi.org/10.1016/j.joi.2010.10.002

12. Craggs R, Park J, Heubeck S, Sutherland D (2014) High rate algal pond systems for low-energy wastewater treatment, nutrient recovery and energy production New Zeal J Bot 52:60-73 doi:https://doi.org/10.1080/0028825X.2013.861855

13. Cruce JR, Quinn JC (2019) Economic viability of multiple algal biorefining pathways and the impact of public policies Appl Energy 233-234:735-746 doi:https://doi.org/10.1016/j.apenergy.2018.10.046

14. Dasan YK, Lam MK, Yusup S, Lim JW, Lee KT (2019) Life cycle evaluation of microalgae biofuels production: Effect of cultivation system on energy, carbon emission and cost balance analysis Sci Total Environ 688:112-128 doi:https://doi.org/10.1016/j.scitotenv.2019.06.181

15. De Bhowmick G, Subramanian G, Mishra S, Sen R (2014) Raceway pond cultivation of a marine microalga of Indian origin for biomass and lipid production: A case study Algal Res 6:201-209 doi:https://doi.org/10.1016/j.algal.2014.07.005

16. de Carvalho JC, Magalhães Al, de Melo Pereira GV, Medeiros ABP, Sydney EB et al. (2020) Microalgal biomass pretreatment for integrated processing into biofuels, food, and feed Bioresour Technol 300:122719 doi:https://doi.org/10.1016/j.biortech.2019.122719

17. de Souza MP, Hoeltz M, Gressler PD, Benitez LB, Schneider RCS (2019) Potential of Microalgal Bioproducts: General Perspectives and Main Challenges Waste Biomass Valori 10:2139-2156 doi:https://doi.org/10.1007/s12649-018-0253-6

18. Emparan Q, Jye YS, Danquah MK, Harun R (2020) Cultivation of Nannochloropsis sp. microalgae in palm oil mill effluent (POME) media for phycoremediation and biomass production: Effect of microalgae cells with and without beads J Water Process Eng 33:101043 doi:https://doi.org/10.1016/j.jwpe.2019.101043

19. Garrido-Cardenas JA, Manzano-Agugliaro F, Acien-Fernandez FG, Molina-Grima E (2018) Microalgae research worldwide Algal Res 35:50-60 doi:https://doi.org/10.1016/j.algal.2018.08.005

20. Gentili FG (2014) Microalgal biomass and lipid production in mixed municipal, dairy, pulp and paper wastewater together with added flue gases Bioresour Technol 169:27-32 doi:https://doi.org/10.1016/j.biortech.2014.06.061

21. Gonçalves AL, Pires JCM, Simões M (2017) A review on the use of microalgal consortia for wastewater treatment Algal Res 24:403-415 doi:https://doi.org/10.1016/j.algal.2016.11.008

22. González LE, Cañizares RO, Baena S (1997) Efficiency of ammonia and phosphorus removal from a colombian agroindustrial wastewater by the microalgae Chlorella vulgaris and Scenedesmus dimorphus Bioresour Technol 60:259-262 doi:https://doi.org/10.1016/S0960-8524(97)00029-1

23. Grierson S, Strezov V, Bengtsson J (2013) Life cycle assessment of a microalgae biomass cultivation, bio-oil extraction and pyrolysis processing regime Algal Res 2:299-311 doi:https://doi.org/10.1016/j.algal.2013.04.004 
24. Jiang Y, Zhang W, Wang J, Chen Y, Shen S et al. (2013) Utilization of simulated flue gas for cultivation of Scenedesmus dimorphus Bioresour Technol 128:359-364 doi:https://doi.org/10.1016/j.biortech.2012.10.119

25. Johnson MB, Wen Z (2010) Development of an attached microalgal growth system for biofuel production Appl Microbiol Biotechnol 85:525-534 doi:https://doi.org/10.1007/s00253-009-2133-2

26. Kothari R, Pathak VV, Kumar V, Singh DP (2012) Experimental study for growth potential of unicellular alga Chlorella pyrenoidosa on dairy waste water: An integrated approach for treatment and biofuel production Bioresour Technol 116:466-470 doi:https://doi.org/10.1016/j.biortech.2012.03.121

27. Kumar AK, Sharma S, Dixit G, Shah E, Patel A (2020) Techno-economic analysis of microalgae production with simultaneous dairy effluent treatment using a pilot-scale High Volume V-shape pond system Renew Energy 145:1620-1632 doi:https://doi.org/10.1016/j.renene.2019.07.087

28. Labbé JI, Ramos-Suárez JL, Hernández-Pérez A, Baeza A, Hansen F (2017) Microalgae growth in polluted effluents from the dairy industry for biomass production and phytoremediation Journal of Environmental Chemical Engineering 5:635-643 doi:https://doi.org/10.1016/j.jece.2016.12.040

29. Levine RB, Costanza-Robinson MS, Spatafora GA (2011) Neochloris oleoabundans grown on anaerobically digested dairy manure for concomitant nutrient removal and biodiesel feedstock production Biomass Bioenerg 35:40-49 doi:https://doi.org/10.1016/j.biombioe.2010.08.035

30. Lincoln EP, Wilkie AC, French BT (1996) Cyanobacterial process for renovating dairy wastewater Biomass Bioenerg 10:63-68 doi:https://doi.org/10.1016/0961-9534(95)00055-0

31. Liu L, Chen J, Lim P-E, Wei D (2018) Enhanced single cell oil production by mixed culture of Chlorella pyrenoidosa and Rhodotorula glutinis using cassava bagasse hydrolysate as carbon source Bioresour Technol 255:140-148 doi:https://doi.org/10.1016/j.biortech.2018.01.114

32. Lowrey J, Brooks MS, McGinn PJ (2015) Heterotrophic and mixotrophic cultivation of microalgae for biodiesel production in agricultural wastewaters and associated challenges - a critical review J Appl Phycol 27:1485-1498 doi:https://doi.org/10.1007/s10811-014-0459-3

33. Lu Y, Zhai Y, Liu M, Wu Q (2010) Biodiesel production from algal oil using cassava (Manihot esculenta Crantz) as feedstock J Appl Phycol 22:573-578 doi:https://doi.org/10.1007/s10811-0099496-8

34. Ma X, Gao M, Gao Z, Wang J, Zhang M et al. (2018) Past, current, and future research on microalgaderived biodiesel: a critical review and bibliometric analysis Environmental Science and Pollution Research 25:10596-10610 doi:https://doi.org/10.1007/s11356-018-1453-0

35. Meireles dos Santos A, Vieira KR, Basso Sartori R, Meireles dos Santos A, Queiroz Ml et al. (2017) Heterotrophic cultivation of cyanobacteria: study of effect of exogenous sources of organic carbon, absolute amount of nutrients, and stirring speed on biomass and lipid productivity Frontiers in Bioengineering and Biotechnology 5 Original Research doi:https://doi.org/10.3389/fbioe.2017.00012

36. Mussatto SI, Machado EMS, Martins S, Teixeira JA (2011) Production, composition, and application of coffee and its industrial residues Food Bioproc Tech 4:661 doi:https://doi.org/10.1007/s11947- 
011-0565-z

37. Pacheco D, Rocha AC, Pereira L, Verdelhos T (2020) Microalgae water bioremediation: trends and hot topics Appl Sci 10:1886 doi:https://doi.org/10.3390/app10051886

38. Panchangam SC, Janakiraman K (2015) Decolorization of aqueous coffee and tea infusions by chemical coagulation Desalin Water Treat 53:119-125

doi:https://doi.org/10.1080/19443994.2013.860401

39. Pleissner D, Lam WC, Sun Z, Lin CSK (2013) Food waste as nutrient source in heterotrophic microalgae cultivation Bioresour Technol 137:139-146

doi:https://doi.org/10.1016/j.biortech.2013.03.088

40. Posadas E, Bochon S, Coca M, García-González MC, García-Encina PA et al. (2014) Microalgae-based agro-industrial wastewater treatment: a preliminary screening of biodegradability J Appl Phycol 26:2335-2345 doi:https://doi.org/10.1007/s10811-014-0263-0

41. Rawat I, Ranjith Kumar R, Mutanda T, Bux F (2011) Dual role of microalgae: Phycoremediation of domestic wastewater and biomass production for sustainable biofuels production Appl Energy 88:3411-3424 doi:https://doi.org/10.1016/j.apenergy.2010.11.025

42. Romaidi, Hasanudin M, Kholifah K, Maulidiyah A, Putro SP et al. (2018) Lipid production from tapioca wastewater by culture of Scenedesmus sp. with simultaneous BOD, COD and nitrogen removal Journal of Physics: Conference Series 1025:012075 doi:https://doi.org/10.1088/17426596/1025/1/012075

43. Roth JCG, Hoeltz M, Benitez LB (2020) Current approaches and trends in the production of microbial cellulases using residual lignocellulosic biomass: a bibliometric analysis of the last 10 years Arch Microbiol 202:935-951 doi:https://doi.org/10.1007/s00203-019-01796-9

44. Rumin J, Nicolau E, Junior RGO, Fuentes-Grünewald C, Picot L (2020) Analysis of scientific research driving microalgae market opportunities in europe Mar Drugs 18 doi:https://doi.org/10.3390/md18050264

45. Selvan ST, Govindasamy B, Muthusamy S, Ramamurthy D (2019) Exploration of green integrated approach for effluent treatment through mass culture and biofuel production from unicellular alga, Acutodesmus obliquus RDS01 Int J Phytoremediation 21:1305-1322

doi:https://doi.org/10.1080/15226514.2019.1633255

46. Strazza C, Del Borghi A, Costamagna P, Gallo M, Brignole E et al. (2015) Life Cycle Assessment and Life Cycle Costing of a SOFC system for distributed power generation Energ Convers Manag 100:6477 doi:https://doi.org/10.1016/j.enconman.2015.04.068

47. Sun C, Xia A, Fu Q, Huang Y, Lin R et al. (2019) Effects of pre-treatment and biological acidification on fermentative hydrogen and methane co-production Energ Convers Manag 185:431-441 doi:https://doi.org/10.1016/j.enconman.2019.01.118

48. Uggetti E, Sialve B, Latrille E, Steyer J-P (2014) Anaerobic digestate as substrate for microalgae culture: The role of ammonium concentration on the microalgae productivity Bioresour Technol 152:437-443 doi:https://doi.org/10.1016/j.biortech.2013.11.036 
49. Umamaheswari J, Shanthakumar S (2016) Efficacy of microalgae for industrial wastewater treatment: a review on operating conditions, treatment efficiency and biomass productivity Reviews in Environmental Science and Bio/Technology 15:265-284 doi:https://doi.org/10.1007/s11157-0169397-7

50. Valizadeh K, Davarpanah A (2020) Design and construction of a micro-photo bioreactor in order to dairy wastewater treatment by micro-algae: parametric study Energ Source Part A: Recovery, Utilization, and Environmental Effects 42:611-624 doi:https://doi.org/10.1080/15567036.2019.1588425

51. Wei A, Zhang X, Wei D, Chen G, Wu Q et al. (2009) Effects of cassava starch hydrolysate on cell growth and lipid accumulation of the heterotrophic microalgae Chlorella protothecoides $\mathrm{J}$ Ind Microbiol Biotechnol 36:1383 doi:https://doi.org/10.1007/s10295-009-0624-x

52. Woertz I, Feffer A, Lundquist T, Nelson Y (2009) Algae grown on dairy and municipal wastewater for simultaneous nutrient removal and lipid production for biofuel feedstock J Environ Eng 135:11151122 doi:https://doi.org/10.1061/(ASCE)EE.1943-7870.0000129

53. Xia A, Cheng J, Ding L, Lin R, Song W et al. (2014) Enhancement of energy production efficiency from mixed biomass of Chlorella pyrenoidosa and cassava starch through combined hydrogen fermentation and methanogenesis Appl Energy 120:23-30 doi:https://doi.org/10.1016/j.apenergy.2014.01.045

54. Yang C-f, Ding Z-y, Zhang K-c (2008) Growth of Chlorella pyrenoidosa in wastewater from cassava ethanol fermentation J Microbiol Biotechnol 24:2919-2925 doi:https://doi.org/10.1007/s11274-0089833-0

55. Yuan X, Kumar A, Sahu AK, Ergas SJ (2011) Impact of ammonia concentration on Spirulina platensis growth in an airlift photobioreactor Bioresour Technol 102:3234-3239 doi:https://doi.org/10.1016/j.biortech.2010.11.019

56. Zhang Y, Su H, Zhong Y, Zhang C, Shen Z et al. (2012) The effect of bacterial contamination on the heterotrophic cultivation of Chlorella pyrenoidosa in wastewater from the production of soybean products Water Res 46:5509-5516 doi:https://doi.org/10.1016/j.watres.2012.07.025

57. Zhu L, Wang Z, Takala J, Hiltunen E, Qin L et al. (2013) Scale-up potential of cultivating Chlorella zofingiensis in piggery wastewater for biodiesel production Bioresour Technol 137:318-325 doi:https://doi.org/10.1016/j.biortech.2013.03.144

\section{Figures}




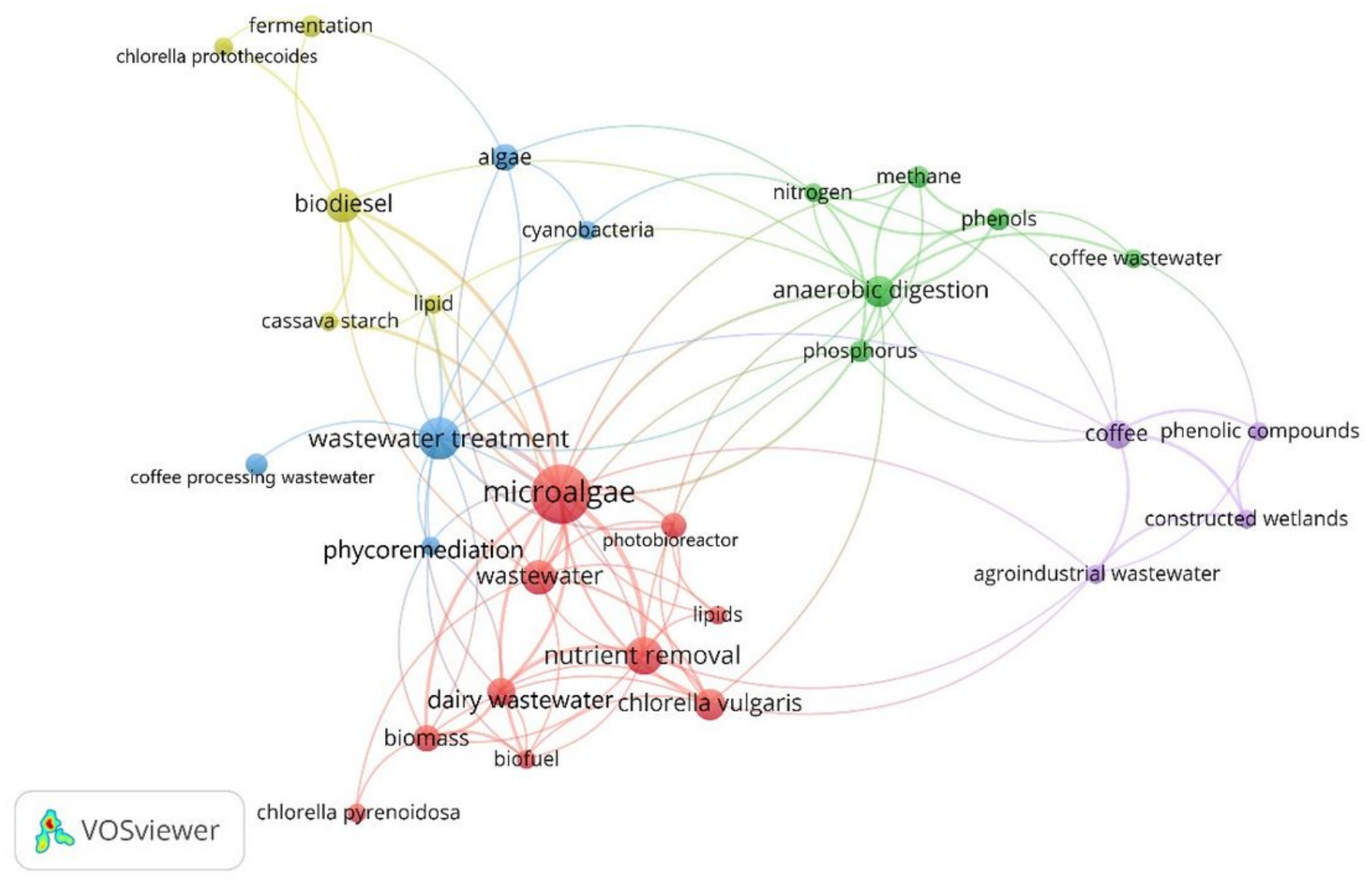

Figure 1

Community of keywords and their associations in publications on agro-industrial effluent treatment in the Web of Science (WoS) database, in the period from 1996 to 2019. Legend: blue cluster= wastewater treatments; yellow cluster = biodiesel from microalgae biomass; green and purple clusters = clean and renewable source of energy and use of coffee wastewater; and red cluster = microalgae, biomass productivity, oil production and nutrient removal. The larger the size of the circle's circumference, the greater the association of the represented word with neighboring words 


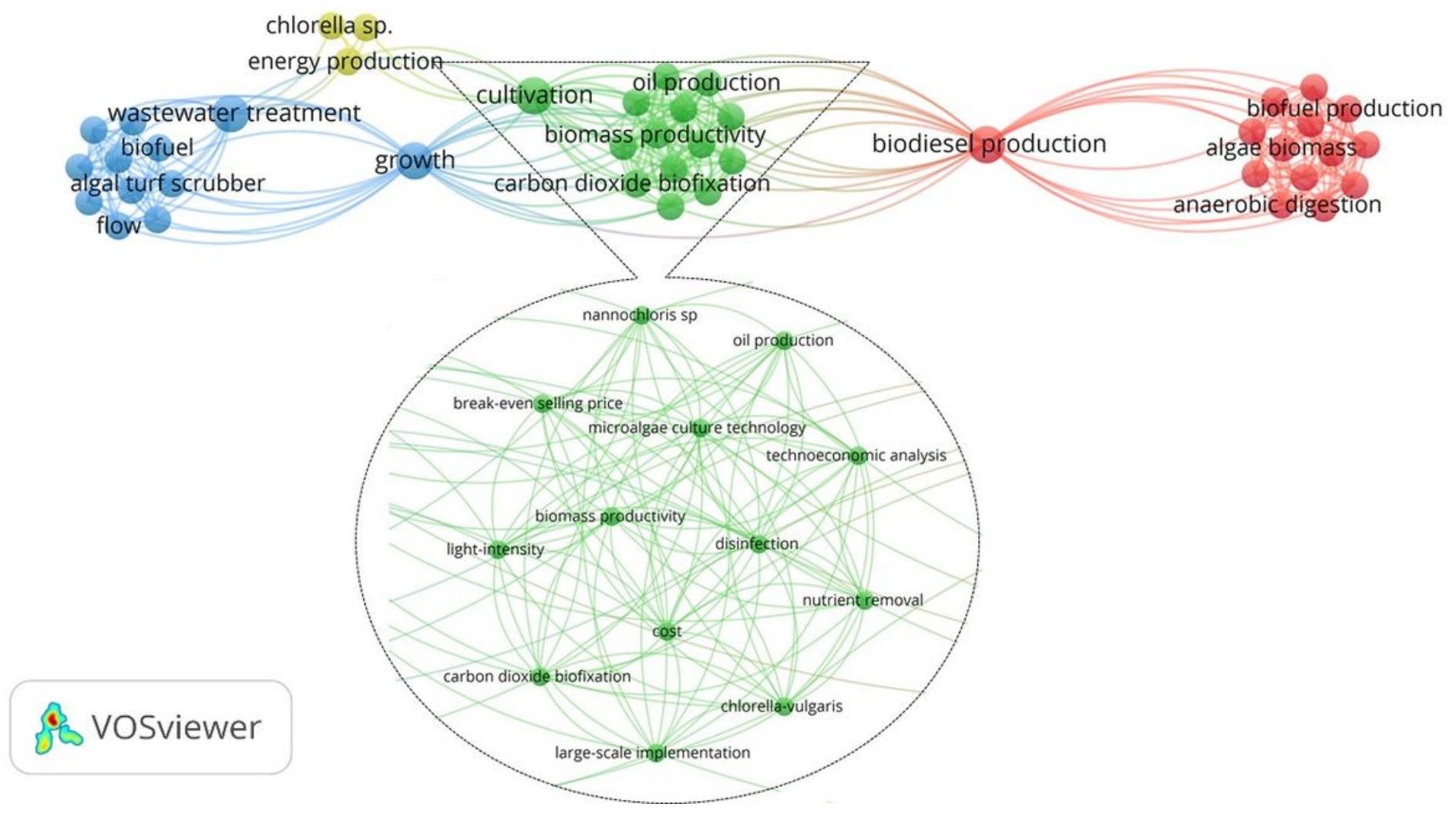

Figure 2

Community of keywords and their associations in publications on agro-industrial effluent treatment in the Web of Science (WoS) database, in the period from 1996 to 2019. Legend: blue cluster = wastewater and synthetic media; yellow cluster = clean and renewable energies; green cluster = biomass productivity, oil production, carbon dioxide biofixation, cost, large-scale production, technoeconomic analysis and nutrient removal; and red cluster = biodiesel from the microalgae biomass 


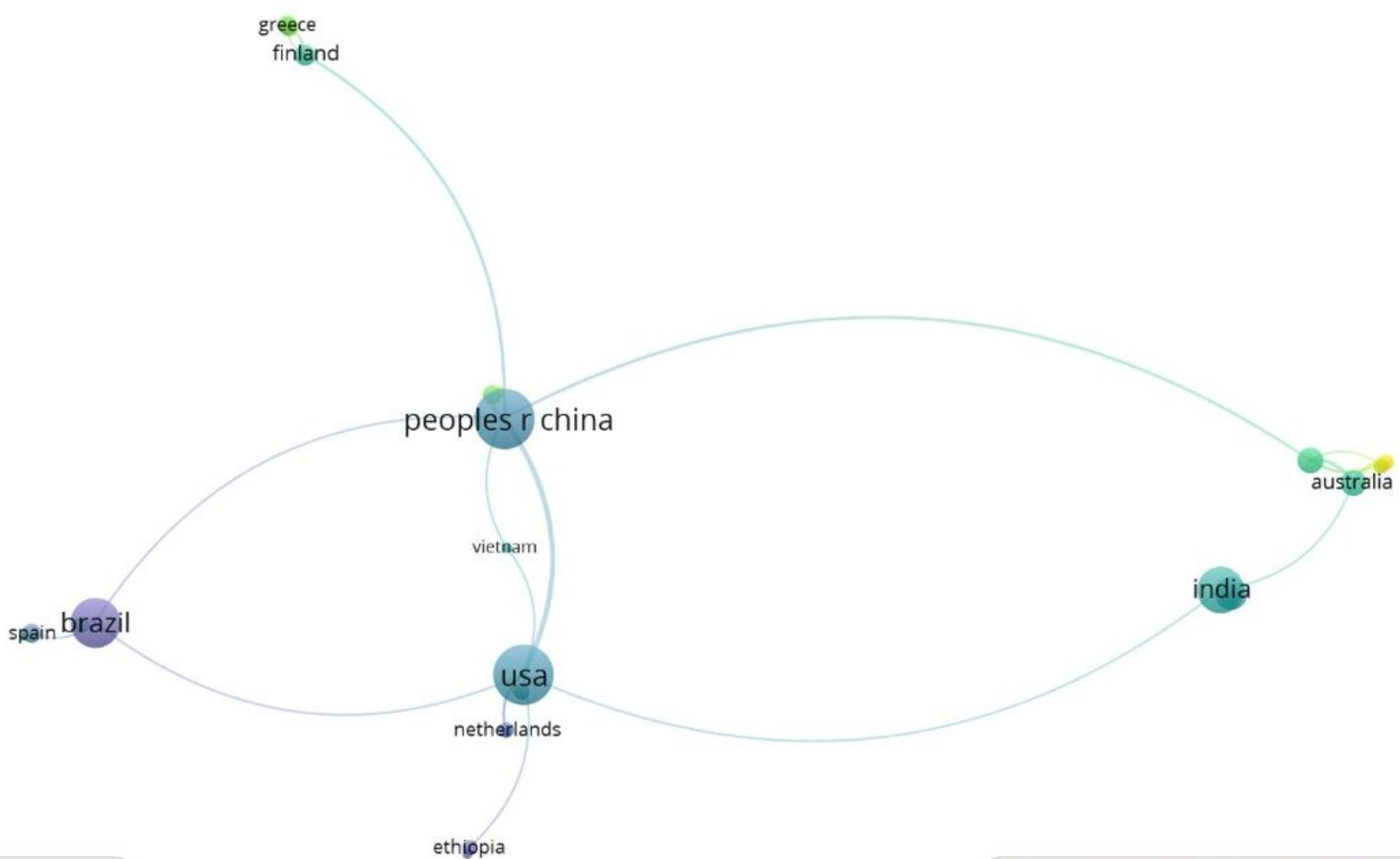

\& Vosviewer

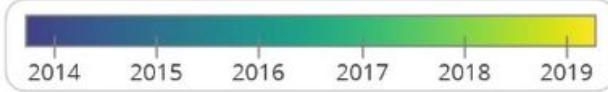

\section{Figure 3}

Community of countries and their publications on treatment of agro-industrial effluents in the Web of Science (WoS) database, in the period from 1996 to 2019 